\title{
Viewpoint
}

\section{Adding Value}

\section{Farmers and ranchers should be compensated for ecosystem services.}

\section{By James L. Maynard}

$\mathrm{T}$ The 2002 Farm Bill must address issues of compensation for the clean air, clean water, wildlife and wildlife habitat produced by the nation's farmers and ranchers if these producers are to stay in business.

The current system is utterly perverse with its negative incentives of "as long as you don't put dust in the air we won't sue", "as long as there is only so much nutrient load in your water, we won't fine you," "as long as you don't harm that animal, we won't throw you in prison."

The clear solution is to make those things that society has indicated as having value, valuable to those who are in a position to provide those commodities. Pay producers for the clean air, clean water, wildlife, and wildlife habitat.

\section{Family Farms In Quandry}

Farmers and ranchers control large amounts of undeveloped land in the United States. Since the Dust Bowl of the 1930's these mostly agricultural acreages have been the focus of numerous conservation programs. A number of programs are regulatory in nature but somewhat indirect in their imposition of alternative conservation practices (e.g., Clean Water Act, Clean Air Act, Endangered Species Act, etc.).

These regulatory and voluntary conservation programs are indicative of society's environmental concern. Society at large desires to have blue skies, sparkling water, and abundant wildlife under the belief that these commodities will make their lives more enjoyable and productive. Most would agree that this is a positive and laudable endeavor.

However, the agricultural operators managing lands which provide these commodities (or ecosystem services) are under increasing regulatory pressure to produce ecosystem commodities in higher quantities and qualities. These regulatory demands impose considerable costs on producers without a return to the investment required to produce the commodities of clean air and water, and wildlife and wildlife habitat. Yet society demands that these ecosystem products be produced as some kind of right to which society is entitled, without compensation to those who produce them in acceptable quantities and qualities.

The new millennium finds many agricultural producers in the United States in dire conditions, especially familysized operations. Technology has made it possible to produce agricultural commodities far in excess of what the U.S. population can consume.

This excess has driven market prices below production costs and is forcing many family operations out of business. Only larger corporate farming entities are able to economically produce food and fiber due to economies of scale which allow them to absorb high production costs. These corporations are also able to retain ownership of raw products vertically through the production chain to capture added value at each level.

As noted by Holechek (2001) policies implemented since World War II, and especially during the 1960's and 1970 's, promoted the use of every possible acre for food production. This resulted in degradation of some of the farmlands and rangelands in the U.S.

Today's society fears the collapse of ecosystems and places blame for the perceived damage to ecosystems on the farmers and ranchers who control and manage the landscapes outside of the urban centers.

The reality that these landowners and producers simply responded to societal signals thirty years ago is not a part of the conversation. A shift in the thinking of both parties is necessary.
Agricultural producers need to think about the commodities they can produce in response to societies' concerns and new value systems. Society needs to consider how to compensate landowners and producers of those commodities which they desire and deem important.

Society needs to realize that lack of compensation for ecosystem commodities and services is driving the very people who can provide those goods and services out of business. The result is the fragmentation of large landscapes, the subdivision of former farms and ranches and thus, further deterioration of the very goods, services, and ecosystems, that society has said through legislation and regulation to be important.

\section{Loss Of Farms Creates Loss Of Understanding The Land}

The disappearance of family farms and ranches is slowly depleting the infrastructure and critical population masses in rural areas. This, too, should be of concern to society. It is my belief that rural communities give value to this nation far in excess of the small amount of support required by the communities themselves.

People on farms and ranches confront, on a daily basis, the reality of absolutes of the natural world. Daily confrontation creates and nurtures an understanding that there are forces in the world greater than ourselves which must be acknowledged. This is often manifested in religious faith and creates within a community a society with absolute demands on its constituents with respect to rules of behavior.

This situation does not hold in the artificial world of the urban centers where the vagaries of nature are blunted. In the urban environment, all becomes relative 
and in a world where interaction with the natural world has become relative, so too are accepted societal behaviors within the artificial world.

But as long as the greater society has among it those who must deal with the absolute realities of the natural world, that society has within it a moral and ethical yardstick with which to measure acceptable behaviors in urban centers.

This, perhaps, is the greater contribution of the rural segments of our society, and if we, who wish to prevent a gradual slide into moral anarchy, should keep and nurture within our society those people who are raised within a community with absolute demands on behavior and responsibility.

This is not meant to imply that there are no moral and ethical people in urban centers or that all rural citizens are infallible. But as each successive generation is further removed from making a living directly from the land, more and more people lose sight of the knowledge of how the natural world functions, the risks that nature imposes, and the costs and responsibilities required to care for the land.

Those in urban environments expect that when a policy, program, law, or regulation is put in place everything should happen just as planned, because that, more often than not, is what occurs in the highly controlled environments of urban centers. This results in unrealistic expectations with respect to what should occur in rural areas where the environment cannot be so tightly controlled.

It takes an enormous amount of time, effort, energy, and money to produce the products and services from the environment that society is demanding and the range of probable outcomes of any practice can be enormous. Yet society demands that this nation's farmers and ranchers produce these products, both commodity and social, without any allowance for risk or cost.

\section{A Win-Win Program}

Payment for ecosystem services will help producers to weather downturns in commodities markets without having government bailout money and continue the longstanding policy of cheap, high quality food this nation has pursued for many years.
It would stabilize the economic and social fabric of our nation's rural communities by providing some level of income certainty decoupled from the vagaries of the natural environment to which producers are inexorably tied.

For those who have concerns regarding the fragmentation of landscapes and wildlife habitats, this could provide a greater incentive for landowners to keep large parcels of farm and ranch land intact due to the additional income stream provided by ecosystem services payments.

Paying farmers and ranchers for ecosystem services will create a new industry of natural resource contractors who will employ people who would formerly have gone to work for the government. They will now be employed in private industry with private health care and retirement, plus contribute to local, state, and federal tax bases which could present an additional opportunity for savings for the Nation's taxpayers.

Clear and measurable standards must be adopted by which producers will be paid. These attributes, whatever they may be, must be measurable and measured by professionals trained to understand the landscapes. Monitoring ecosystem services can be provided by independent contractors, many of whom can be found in the Range Management profession, who are professionally trained to collect and interpret the data. Landowners and producers would not fear people coming on their land since they would select the contractors with whom they are comfortable.

This would not be a give away program. Producers and agricultural operators would be compensated for products they produce which contribute to the greater good of society.

If an owner/manager does not meet established standards for the area with respect to air quality, water quality and adequate wildlife habitat, or whatever attributes are appropriate for that vegetative type or soil type, that individual would simply not be paid.

Nor would this be a call for the repeal of the regulatory structure already in place. All landowners would still be liable for pollution or other harmful effects to ecosystems.

\section{Utilize FSA's Structure}

The mechanism to implement a payment for ecosystem services is already in place. The Farm Service Agency (FSA) currently administers a number of farm programs such as the Conservation Reserve Program, Conservation Reserve Enhancement Program, Emergency Conservation Program, and the Environmental Quality Incentives Program. Since the ecosystem services program is similar to existing programs and may in fact negate the need for several of these programs, FSA would operate the ecosystem services program in a similar manner.

The current system consists of local boards who understand the landscape and ecology of the area, are familiar with the costs of implementing management within the area, and have the experience to understand the needs of the community. The FSA implements programs under its jurisdiction according to standards and review of these local boards.

The constant battle over natural resources management of either private or federal land does not produce beneficial results. Neither side customarily puts workable solutions on the table and ultimately it is the resource that loses.

This proposal will: 1) Promote workable solutions for all members of society; 2) Ensure that this Nation's valuable natural resources are properly used and conserved and; 3 ) That those who steward natural resources are able to continue their stewardship.

Paying producers for ecosystem products and services from their lands requires only monitoring the results of their management and writing them a check based on the results.

Author is owner and principle of Southwest Resource Consultants, 10609 N. Hwy 85, Las Cruces, New Mexico 88005.

\section{References}

Holechek, Jerry L. 2001. Western Ranching at the Crossroads. Rangelands. 23(1):17-21. 